\title{
Crop geometry effects on relative humidity variation within wheat crop
}

\section{SARABJOT KAUR SANDHU AND L.K. DHALIWAL}

Article Chronicle:

Received:

03.05.2016;

Revised :

06.05.2016;

Accepted :

23.05.2016

Key Words :

Crop geometry, Microclimate, Row spacing, Row direction, Relative humidity
ABSTRACT : The present investigation was carried out at Research Farm, School of Climate Change and Agricultural Meteorology during 2012-13 and 2013-14. This study was planned to know the role of agronomic manipulation i.e., change in row spacing and row direction in relative humidity profile within crop. The investigations were done under two field experiments. In first experiment, three wheat varieties viz., HD 2967, PBW 550 and PBW 343 were sown under three row spacing i.e., $15 \mathrm{~cm}, 22.5 \mathrm{~cm}$ and $30 \mathrm{~cm}$ on $25^{\text {th }}$ November during both crop seasons. In second experiment three varieties of wheat viz., HD 2967, PBW 550 and PBW 343 were sown under two row directions viz., North-South and EastWest on $25^{\text {th }}$ November during both crop seasons. The experiments were laid out in Split Plot Design, by keeping varieties in main plot and row spacing or row direction in sub plot. Diurnal cycles of relative humidity within crop canopy were recorded. Relative humidity was highest in $15 \mathrm{~cm}$ row spacing followed by $22.5 \mathrm{~cm}$ and $30 \mathrm{~cm}$. In $15 \mathrm{~cm}$ row spacing almost 4 per cent more relative humidity was recorded than $30 \mathrm{~cm}$ row spacing. Among different row directions, more relative humidity was recorded in North-south row direction. This study indicated that microclimate of a crop can be modified by changing crop geometry.

HOW TO CITE THIS ARTICLE : Sandhu, Sarabjot Kaur and Dhaliwal, L.K. (2016). Crop geometry effects on relative humidity variation within wheat crop. Asian J. Environ. Sci., 11(1): 94-101, DOI: 10.15740/HAS/ AJES/11.1/94-101.
Author for correspondence :

\section{SARABJOT KAUR} SANDHU

School of Climate Change and Agricultural Meteorology, Punjab Agricultural University, LUDHIANA (PUNJAB) INDIA

See end of the article for Coopted authors' 